\title{
Penelitian
}

\section{Analisis Rencana Penerapan Sistem Informasi Dalam Pendokumentasian Asuhan Keperawatan Di Rumah Sakit Universitas Tanjungpura}

\section{(Analysis Of Implementation Of Information System In Documenting Nursing Care At Hospital Of Tanjungpura University)}

\author{
Arizal $^{1}$, Ichsan Budiharto ${ }^{2}$, Arina Nurfianti ${ }^{2}$ \\ ${ }^{1}$ Mahasiswa Program StudiKeperawatanUniversitas \\ Tanjungpura \\ ${ }^{2}$ Dosen Program Studi Keperawatan \\ UniversitasTanjungpura e-mail : \\ rizal@student.untan.ac.id
}

\begin{abstract}
Abstrak
Latar belakang: Sistem informasi dalam keperawatan merupakan komponen kunci dalam pemberian asuhan keperawatan modern dan sebagai kunci untuk meningkatkan kualitas pelayanan keperawatan. Rumah Sakit Universitas Tanjungpura memiliki fasilitas dan sumber daya manusia dalam yang mendukung dalam menggunakan sistem informasi dalam proses asuhan keperawatan berbasiskomputer.

Tujuan: Untuk menganalisis proses penerapan sistem informasi dalam pendokumentasian asuhan keperawatan di Rumah Sakit UniversitasTanjungpura.

Metode: Desain kualitatif deskriptif pendekatan fenomenologi, diambil dengan wawancara mendalam. Hasil penelitian dianalisis menggunakan metode Miles dan Huberman.

Hasil: Penelitian ini teridenfikasi empat tema yaitu Pelaksanaan pendokumentasian terintegrasi dengan dua kategori yaitu orientasi terhadap dokumentasi dan kelemahan paper base, Pemahaman tentang pendokumentasian berbasis komputerisasi dengan dua kategori yaitu kemudahan terhadap komputerisasi dan pengetahuan, Persiapan perawat dalam proses penerapan SIMRS dengan tiga kategori yaitu persepsi perawat terhadap penerapan SIMRS, wacana publik dan pengembangan perawat, dan Penghambat dalam penerapan sistem informasi dalam pendokumentasian asuhan keperawatan dengan tiga kategori yaitu sumber daya manusia tenaga ahli IT, fasilitas dan ketidaksamaan visi dalam birokrasi.

Kesimpulan: Rencana penerapam sistem informasi dalam pendokumentasian keperawatan Rumah Sakit Universitas Tanjungpura dipengaruhi oleh perawat, manfaat dalam peningkatkan kinerja dan mutu pelayanan dan pengetahuan perawat, selanjutnya didukung dengan tenaga infomatika, fasilitas dan manajemen rumah sakit.
\end{abstract}

Kata Kunci: Pendokumentasian, sistem informasi, keperawatan 


\title{
(Analysis Of Implementation Of Information System In Documenting Nursing Care At Hospital Of Tanjungpura University)
}

\author{
Arizal $^{\star}$, Ichsan Budiharto ${ }^{\star *}$, Arina Nurfianti ${ }^{\star *}$ \\ Department of Nursing, Faculty of Medicine, Tanjungpura University, Indonesia
}

Correesponding Author's Email :rizal@student.untan.ac.id

\begin{abstract}
Background: The information system in nursing is a key component in the provision of modern nursing care and as a key to improve the quality of nursing services. Tanjungpura University Hospital has facilities and human resources power in supporting in using information system in process of computer based nursingcare.

Aim: To analyze the process of applying information systems in documenting nursing care at Tanjungpura UniversityHospital.

Method: The descriptive qualitative design of the phenomenological approach, taken with in-depth interviews. The results were analyzed using Miles and Huberman methods. Results: This study identified four themes: Implementation of integrated documentation in two categories: orientation to documentation and weakness of paper base, understanding of computerized documentation in two categories: ease of computerization and knowledge, nurse preparation in SIMRS implementation process with three categories, nurse's perception on application SIMRS, public discourse and nurse development, and barriers in the application of information systems in documenting nursing care with three categories namely human resources IT experts, facilities and unequal vision in thebureaucracy.

Conclusion: The plan for applying information system in documentation process nursing of Tanjungpura University Hospital is influenced by the nurses, the benefits in improving the performance and the quality of service and knowledge of the nurse, then supported by the infomative staff, facilities and hospital management.
\end{abstract}

Keywords: Documenting, information systems, nursing 


\section{PENDAHULUAN}

Sistem informasi secara luas dianggap sebagai kunci untuk meningkatkankualitaspelayanankesehatan

1]. Kegunaan sistem informasi yaitu menyimpan data tentang semua kegiatan yang tujuan utamanya adalah untuk mempromosikan,

memulihkanataumempertahankankesehat

$\mathrm{an}^{[2]}$. Sistem informasi dalam keperawatan merupakan dasar ilmu pengetahuan yang mengintegrasikan ilmu komputer dalam mengelola data, dan pengetahuandalampraktekkeperawatan ${ }^{[3]}$. Sistem informasi dalam keperawatan merupakan komponen kunci dalam pemberian asuhankeperawatan modern ${ }^{[4]}$. Pengaruh sistem informasi keperawatan pada kualitas pengolahan informasi keperawatan, hasil survey pertama diperoleh sebanyak $75 \%$ perawat merasa nyaman dalam menggunakan komputer dan survey kedua mengalami peningkatan menjadi 93\%, kemudian dilakukan survey sebelum dan sesudah, diperoleh perawat mengatakan sangat penting dokumentasi berbasis komputer. Dilakukan selanjutnya survey sebelum berdasarkan pengenalan komputer maka diperoleh perawat menghabiskan waktu $1 / 4$ dari waktu mereka untuk dokumentasi.Setelah dilakukan pelatihan secara signifikan meningkat menjadi $41 \%$.

Berdasarkan efisiensi diperoleh, bahwa sebelumnya perawat merasa khawatir dapat mengurangi efesiensi, dilakukan survey sesudah terjadi peningkatan kualitas pengolahan informasi dalam keperawatan yaitu lebih cepat akses informasi, mudah merubah rencana keperawatan, menghindari dokumentasi tumpang danpenggunaanlebihmudah ${ }^{[5]}$.

Orlando menggunakan istilah proses keperawatan untuk menjelaskan asuhan keperawatan. Langkah-langkah dalam proses ini dikaitkan dengan metode ilmiah, seperti:pengumpulan data (pengkajian) merumuskan diagnosis, intervensi, implementasi danevaluasi ${ }^{[6]}$.
Kerangka kerja yang menghubungkan komponen fundamental keperawatan, proses keperawatan, dengan prinsipprinsip interaksi perawat dengan komputer. Diperoleh hasil, bahwa pengguna sistem informasi berperan dalam lintasan perawat dengan pasien dapat mengurangi hambatan klinis, seperti alur kerja, efesiensi dan kualitas pelayanan pasien rawatinapdapatmeningkat ${ }^{[7]}$.

Sistem Informasi diperlukan untuk memberikan, mengordinasikan, dan juga mengintegrasikan pelayanan rumah sakit.Hal ini meliputi ilmu pengasuhan pasien secara individual, asuhan yang diberikan.dan kinerja staf klinis. Sistem Informasi merupakan sumber daya yang harus dikelola secara efektif oleh pimpinan rumah sakit seperti halnya sumber daya manusia, material, dan finansial.Setiap rumah sakit berupaya mendapatkan, mengelola, dan menggunakan informasi untuk meningkatkan/ memperbaiki hasil asuhan pasien, kinerja individual, serta kinerja rumah sakit secara keseluruhan. Pengelolaan pendokumentasian dan Sistem informasi adalah menunjang tertib administrasi dalam rangka upaya peningkatan pelayanan kesehatan di rumah sakit yang didukung oleh suatu sistem pengelolaan pendokumentasian yang cepat, tepat, bernilai, dapat dipertanggungjawabkan, serta berfokus pada pasien dan keselamatanpasiensecaraterintegrasi ${ }^{[8]}$. Hasil studi pendahuluan yang dilakukan oleh peneliti di Rumah Sakit Universitas Tanjungpura Januari 2018 diperoleh bahwa Rumah Sakit memiliki fasilitas yang mendukung dalam menggunakan sistem informasi dalam proses asuhan keperawatan berbasis computer. Fenomena yang ada pada saat ini, setiap ruangan memiliki unit computer, jaringan internet, namun jumlah SDM Perawat yang dimiliki belum memadai dalam melaksanakan asuhan keperawatan berbasis sistem informasi/computerisasi.Hal ini dikarenakan dari 94 jumlah perawat, baru $10-15 \%$ yangsudah 
mengikuti pelatihan pendokumentasian asuhan keperawatan secara non sistem/bukan berbasis sistem informasi (SI) dan belum ada yang mendapatkan pelatihan pendokumentasian asuhan keperawatan berbasis sistem informasi serta rumah sakit juga belum menerapkan Sistem Informasi Rumah Sakit(SIRS).

Berdasarkan hasil observasi yang dilakukan oleh peneliti, yaitu tentang proses pelaksanaan asuhan keperawatan dari tahap pengkajian, diagnosa keperawatan, intervensi, implementasi, evaluasi di Rumah Sakit Universitas Tanjungpura, maka diperoleh proses pendokumentasian belum optimal. Pada bagian assessment/pengkajian perawat hanya melakukan pengkajian sesuai keluhan pasien saja.Tahap Intervensi perawat hanya menulis rencana sesuai instruksi dokter saja tanpa ada intervensi sesuai standar Nursing Intervention Clasificstion (NIC).Pendokumentasian implementasi keperawatan, perawat sering melakukan kesalahan.Adanya catatan perkembangan yang sudah ditulis sebelum waktunya dan duplikasi catatan perkembangan hari demi hari. Perawat tidak mendokumentasikan hal-hal apa saja yang dilakukan, sehingga terjadi kesenjangan antara dokumentasi dan implementasi yang telah dilaksanakan. Pada tahap evaluasi di bagian assesment, banyak perawat yang tidak menganalisis mengapa masalah yang muncul tetap ada, sehingga pada tahapPerencanaan perawat tidak memodifikasi intervensi yangada.

Dalam menuliskan diagnosa masih belum memenuhi/sesuai dengan standar NANDA sehingga takstandarasuhankeperawatan.Pengisianp endokumentasianasuhankeperawatan yang tidak optimal disebabkan oleh perawat yang multifungsi, dimana perawat melakukan tindakan yang bukan tindakan keperawatandankurangmemahamidalampr oses pendokumentasiansehinggaasuhan keperawatan tidak didokumentasian secara rinci.

Berdasarkan uraian fenomena diatas peneliti tertarik untuk melakukan penelitian tentang Analisis Rencana Penerapan Sistem Informasi dalam Pendokumentasian Asuhan Keperawatan di Rumah Sakit UniversitasTanjungpura.

\section{METODOLOGI PENELITIAN}

Penelitian kualitatif dengan pendekatan fenomenologi deskriptif.Lokasi di Rumah Sakit Universitas Tanjungpura.Penelitian dilaksanakan pada bulan Mei 2018.Jumlah partisipan seluruhnya adalah tujuh orang yang terdiri dari semua perempuan.Usia partisipan berkisar antara 26 tahun hingga 32 tahun. Partisipan yang dijadikan reponden dalam penelitian ini adalah kepala bidang keperawatan, tiga kepala ruangan, dua kepala tim keperawatan dan satu perawat pelaksana

Data dikumpulkan dengan metode wawancara mendalam semi terstruktur dengan waktu 15-30 menit dan direkam dengan alat perekam. Hasil wawancara di transkripsikan kemudian dianalisis menggunakan metode Miles and Huberman dengan menggunakan tiga unsur yaitu reduksi data, penyajian data dan penarikan kesimpulan. Validitas dan reliabilitas dalam penelitian ini ditetapkan dengan menggunakan kriteria keabsahan data. Untuk menetapkan keabsahan suatu data, diperlukan teknik pemeriksaan yang didasarkan 4 kriteria yaitu uji credibility, confirmabilit, dependability dantransferability ${ }^{[9]}$.

\section{HASIL DAN PEMBAHASAN \\ Pelaksanaanpendokumentasianterintegr asi}

Kegiatanpendokumentasiankepera watanberdampakpada peningkatan mutupelayananasuhankeperawatanyang 
diberikan. Pendokumentasian keperawatan bermanfaat untuk meningkatkan kinerja perawat, meningkatkan kualitas pemberian asuhan keperawatan. Jika pendokumentasian dilaksanakan sesuai dengan standar dan format akan berdampak bagi kualitas pemberian asuhan keperawatan salah satunya meningkatkan mutu pelayanan yang diberikan ke pasien, selain itu juga untuk mengontrol asuhan keperawatan yang diberikan juga dapat dipertanggungjawabkan secara moral dan hukum pada perawat yang melaksanakan pendokumentasian.

(P4)...." kalau misal dari rumah sakit ini sih dalam masalah dokumentasi kami masih melalui ini metode tertulis yang ee formatnya yang diberi kan oleh sesuai rumah sakit eee segala sesuatu sih di isi di situ yang kita lakukan ke pasien, apa yang mau kita rencanakan, e semuanya di tulis di dalam formatitu".

(P5)....." Waktu dan pasti akan ada loss

!...... Loss informasi dan akhirnya nanti paling kita feedback ulang lagi itu".

Faktor sarana penunjang yang disediakan rumah sakit termasuk format dokumentasi (naratif atau checklist) dan faktorperawatsebagaipelaksana $^{[10]}$.

Lingkungan fisik termasuk fasilitas (format dokumentasi) dapat memberikan dampak signifikanterhadapkinerjaperawat $^{[10]}$.

Pencatatan data klien yang lengkap dan akurat akan memberikan kemudahan bagi perawat dalam membantu menyelesaikan masalah klien dan mengetahui sejauh mana masalah klien dapat teratasi, hal ini akan

membantumeningkatkanmutupendokumen tasianasuhankeperawatan $^{[11]}$.

Berdasarkan hasil analisis data penggunakan sistem pendokumentasi menggunakan metode paper base atau menulis tersebut membutuhkan waktu yang lama untuk menulis status pasien sehingga mempengaruhi kinerja dan pelayana keperawatan. $\mathrm{Hal}$ ini di karenakan instrument/format statuspasien yang banyak dari pengkajian sampai evaluasi tindakan sehingga waktu yang dibutuhkan untuk menulis status pasien memakan waktu yang lama.

Perawat menghabiskan waktu $1 / 4$ dari waktu merekauntukmenulisdokumentasi ${ }^{[5]}$.

Pengguna sistem informasi berperan dalam lintasan perawat dengan pasien dapat mengurangi hambatan klinis, seperti alur kerja, efesiensi dan kualitas pelayanan pasien rawatinapdapatmeningkat ${ }^{[7]}$. Penggunaanproses

keperawatansebagaikerangka kerja yang bermanfaat bagipasiendanperawat ${ }^{[12]}$.

Pendokumentasian dengan paper base dilaksanakan terus menerus akan berdampak bagi kualitas pemberian asuhan keperawatan salah satunya dapat menurunkan mutu pelayanan yang diberikan dengan kata lain pihak manajemen Rumah Sakit harus memperhatikan dan dapat mengatasi faktor yang memengaruhi lamanya waktu dalam pendokumentasian seperti yang telah disebutkan di atas, maka waktu kerja perawat akan efisien, meningkatkan kualitas asuhan keperawatandanmutupelayanan.

\section{Pemahaman dalam pendokumentasian berbasis komputerisasi}

Pemahaman

tentang pendokumentasian berbasis komputerisasi sangatlah berpengaruh dalam pelayanan keperawatan khususnya dalam menerapkan sistem informasi pendokumentasian asuhan keperawatan berbasis komputerisasi di rumah sakit, seperti yang dikutip dalam wawancara berikut;

(P5)....."Sudah waktu praktek profesi... kitanya hanya klik-klik di kotak sampingnya kita mau ngunakan yang mana-mana udah"

(P6)....."ndak tahu karena kita belum ada perbandingan, siapa tahu dengan komputerisasi malah tambah ribet".

Kualifikasi perawat di Rumah Sakit Universitas Tanjungpura sudah 
banyak lulusan Ners sehingga tingakat pemahaman dan pengetahuan terhadap manfaat dan cara kerja program pendokumentasian berbasis komputerisasi oleh perawat rumah sakit Universitas Tanjungpura sudah siap untuk di terapkan sistem ini.

Ditinjau dari perawat sudah pernah lihat, mendengar dan melakukan sistem komputerisasi dalam pendokumentasian.Pendokumentasian berbasis komputerisasi bahwa penggunaan sistem informasi berperan dalam lintasan perawat dengan pasien dapat mengurangi hambatan klinis, seperti alur kerja, efesiensi dan kualitas pelayanan pasien dapat meningkat.

Sistem informasi dalam keperawatan merupakan komponen kunci dalam

pemberianasuhankeperawatanmodern ${ }^{[4]}$.

Sistem informasi dalam keperawatan merupakan dasar ilmu pengetahuan yang mengintegrasikan ilmu komputer dalam mengelola data, dan pengetahuandalampraktekkeperawatan ${ }^{[3]}$. Komputer akan membuat pekerjaan perawat menjadi lebih mudah dan memberikan kesempatan untuk mengerjakan tugas-tugas professionalnya, serta

mengurangiresikopencatatanberulang ${ }^{[14]}$.

Penggunaan Electronic Health Records (EHR) mempunyai hubungan yang signifikan dengan kualitas dan kepuasan perawat terhadap electronic medical records $(E M R)^{[15]}$. Kegunaan sistem informasi yaitu menyimpan data tentang semua kegiatan yang tujuan utamanya adalah untuk mempromosikan, memulihkanataumempertahankankesehat $\mathrm{an}^{[2]}$.

Hasil dari analisis data menunjukan pandangan perawat terhadap sistem pendokumentasian berbasis komputerisasi itu memudahkan dalam pelaksaan pendokumentasian keperawatan baik dari keefisienan waktu, pencaatan yang rapi dalam dokumentasi tindakan dan perkembangan pasien. Berdasarkan hasil penelitian yang dilakukan bahwa tingkat pengentahuan partisipan di Rumah Sakit Universitas Tanjungpuraterhadap pendokumentasianberbasiskomputerisasis udahbaik karenakanadabeberapapartisipan yang sudahmendengar, melihanbahkan pernahmelakukanpendoku mentasianberbasiskomputerisasi.

\section{Persiapan Perawat Dalam Proses Penerapan SIMRS}

Penerapanpendokumentasianberba siskomputerisasisangat penting untuk meningkatkan kualitas mutu pelayanan, kinerja perawat dan keefisienan waktu dalam proses dokumentasi. Harapan partisipan agar Rumah Sakit ini dapat segera mengrelasasikan aplikasi pendokumentasasian berbsis komputerisasi sehingga beban kerja perawat berkurang dan waktu untuk ke pasien lebih banyak dalam pemberian dan tindakan asuhan keperawatan ke pasien.seperti yang dikutip dalam wawancara berikut;

(P1)....."bahwa kedepannya saya ingin sekali bahwa,,,, iya menggunakan sistem informasi. SIMRS itu".

(P5)....."kami dari keperawatan pasti akan mendukung sekali sistem informasi rumah sakit terutama bidang untuk pendokumentasian keperawatanya karena bertujuan juga untuk kenyamanan untuk kita berkerja, terus tu waktu bukti kita berkerja, terus untuk perlindungan hukum untuk kita nanti saatberkerja".

Pelayanan keperawatan yang berkualitas hanya dapat diwujudkan dengan pemberianpelayanan yang professional $^{[16]}$. Sistem informasi merupakan salah satu atribut yang bermanfaat dalam meringankan proses dokumentasi dalam perawatan sekaligus menciptakan

sejumlahtantangandokumentasibaru ${ }^{[17]}$.

Pelatihan merupakan faktor yang dominan mempengaruhi

perawatdalamkelengkapandokumentasi ${ }^{[18]}$. Hasil dari analisa data, partisipan mengatakan diperlukannya pelatihanpelatihan khusus untuk pendokumentasian berbasis komputerisasi untuk meningkatkan kinerja dan mutupelayanan. 
Partisipan mengatakan memang perlu dilakukan pelatihan khusus untuk pendokumentasian berbasis komputerisasi, guna untuk mengetahui uraian dan tahap pengoprasian program.Pelatihan juga diharapkan dapat untuk menyeragamkan pemahaman dalam pelaksanaan pendokumentasian, sehingga antara perawat satu tidak ada yang tidak mengerti dalam pengoprasikan program. Artinya semakin sering diadakan pelatihan dan pengembangan yang dilakukanpengelola Rumah Sakit Universitas Tanjungpura maka semakin siap perawat akan pelaksaan dan pengimplementasianpendokumentasianbe rbasiscomputer.

\section{Penghambat Dalam Penerapan Sistem Informasi Dalam Pendokumentasian Asuhan Keperawatan}

Sumberdayamanusiadalambidang nformasiTeknologi

FasilitasdanKebijakanmerupakanbagianter pentingdalam

penerapanpendokument asianberbasiskomputerisasi.Penerapan sistem informasi dalam pendokumentasian dapat mempengaruhi mutu pelayanan keperawatan di Rumah Sakit. hambatan dalam penerapan sistem informasi dalam pendokumentasian asuhan keperawatan di Rumah Sakit Universitas Tanjungpura ini disebabkan karena Rumah Sakit ini kekurangan tenga ahli teknik informatika untuk dijadikan sebagai Informasi Teknologi (IT) rumah sakit, fasilitas yang masih kurang mendukung selain itu juga belum adanya kebijakan dalam bentuk peraturan mengikat (SK penerapan sistem informasi dalam pendokumentasian), ketidaksaaan visi dalam birokrasi Rumah Sakit dan anggaran, seperti di kutip dalam wawancara berikut;

(P7)....."kita tidak punya IT".

(P3)....."Kalau mau terapkan itu sih pasti fasilitasnya ya agak susah...... walaupun komputer setiap ruangan ada tapi kan kalau memang sudah menggunakan itu kan tetap harus jaringan internetnya harus kuat juga"

(P2)....."pengajuan apa-apa itu lambat proses, panjang,,, harus memiliki alasan yang kuat baru bisa terACC dan ini dana yang besar juga jadi ndak dengan mudah kitaminta".

Upaya yang dapat dilakukan untuk meningkatakan kepuasan perawat adalah dengan mempersiapkan sarana dan prasarana untuk penerapan sistem dan mengembangkan sistem pengawasan Hospital Acquired Infections HAls Agar dapat terintegrasi dengan sistem di RumahSakit $^{[18]}$. Penggunaan Electronic Health Records (HER) mempunyai hubungan yang signifikan dengan kualitas dan kepuasan perawat terhadap Electronic

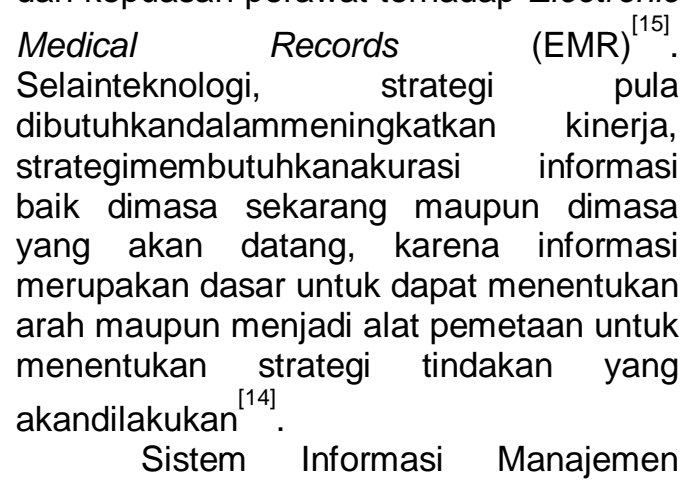
(SIM) dapat memenuhi kebutuhan Rumah Sakit dalam mempercepat pelayanan, menyajikan data dan merekam data yang benar sehingga memperlancar pelayanan pasien. Akan tetapi disini entry data kadang-kadang dilakukan secara bergantian baik oleh dokter oleh perawat yang dimana pengisian datanya tidak lengkap mengingat petugas khusus hanyaterdapat 1 orang $^{[19]}$. SIMRS di Rumah Sakit seperti ketersediaan infrastruktur, keorganisasian, dukungan manajemen dan pendanaan, kebijakan nasional dan ketersediaan sumber daya manusia. Dukungan SDM teknis menjadi salah satu kunci keberhasilan penerapan SIMRS yang berkesinambungan ${ }^{[20]}$. Hambatanpelaksanaanpenerapan sistem komputerisasi ialah belum ada nota kesepakatan penerapan SIMRS antara 
pihak rektorat dan manajemen Rumah Sakit baik pengadaan aplikasi, fasilitas, sumber daya manusia dan pengembangan perawat dengan rutin melakukan dan mengikuti pelatihan dan workshop. Pendokumentasian merupakan hal yang penting, karena merupakan bukti pencatatan dan pelaporan yang dimiliki perawat untuk dijadikan sebagai bahan evaluasi.Pada hal ini seharusnya menjadi pendukung dalam pelaksanaan penerapan sistem informasi dalam pendokumentasian namun sebaliknya malah menjadi penghambat, menghambatpenerapannya.

\section{KESIMPULAN}

Kesimpulan penelitian yaitu :

1. Permahaman mengenai pendokumentasian terintegrasi di Rumah Sakit Universitas Tanjungpura ialah orientasi terhadap dokumentasi dan kelemahan paperbase

2 Pemahaman tentang penerapan dalam pendokumentasien berbasis komputerisasi terhadap manfaat dan pengoprasiannya aplikasi dalam mengurangi bebankerja

3. Persiapan Perawat dalam proses penerapan SIMRS ialah persepsi perawat terhadap SIMRS, wacana publik dan pengembangan perawat sehingga mengharapkan SIMRS segera terelasasikan karena lebih efisien dalam meningkatkan mutu dan kinerja perawat karena tidak merepotkan perawat saatberkerja.

4. Penghambat dalam penerapan sistem informasi dalam pendokumentasi

asuhan keperawatan ialah sumber daya manusia tenaga ahli informasi teknologi (IT), Fasilitas dan

ketidaksamaanvisidalambirokrasi.

\section{DAFTAR PUSTAKA}

1. Palvia, P., Lowe, K., Nemati, H., \& Jacks, T. Information technology issues in healthcare: hospital CEO and $\mathrm{ClO}$ perspectives. Journal Information Technology Issues in Health Care, 2014; 30 (1), 294-312.Ramadhan, B. M., Ssenyonga, T., \& Sumil,R. N. Development and implementation of patient management information system of Kampala International University Teaching Hospital (KIU$\mathrm{TH})$, Bushenyi District, Uganda.An Open Access International Journal, 2014; 4, 77- 83.

2. Daniel, O. G., \& Oyetunde, O. M. Nursing informatics: A key to improving nursing practice in Nigeria. Journal International of Nursing and Midwifery, 2013; 5, 91-98.

3. While, A., \& Dewsbury, G. Nursing and information and communication technology (ICT): Adiscussion of trends and future directions. Journal International of Nursing Studies, 2013; 48,1302-1320.

4. Ammenwerth, E., Rauchegger, F., Ehlers, F., Hirsch, B., \& Schaubmay, C. Effect of a nursing information system on the quality of information processing in nursing: An evaluation study using the HIS-monitor instrument. International Journal of Medical Informatics, 2011; 80,25-38.

5. Vieira J, L., Salviano M, E, M., Goncalves L., Chianca M, C, T., Carvalho, D, V., \& NascimentoT, B. Strategis for the deployment of systematization of strategis of nursing in a university hospital. Journal of Nursing, 2014; 8, 2186 2193.

6. Alexander, G. L. The nursepatient trajectory framework. Journal Technology Health Care, 2007; 2,1-9.

7. Komisi Akreditasi Rumah Sakit. Standar NasionalAkreditasi 
Nomor ISSN : 2338-4700 / SK no. 0005.0102/JI.3.2/SK.ISSN/2013.06

\& | BIMIKI / Volume 7 No2 | Juli - Desember 2019 
Rumah Sakit. Ed.1. KARS-Dirjen BUK. 2017.

8. Sugiyono. (2017). Metode Penelitian Kuantitatif dan Kualitatif. Bandung:Alfabeta.

9. Wahyudi, Udi., Rejeki, Sri., \& Ulliya, Sarah. Pengaruh Penggunaan Format Dokumentasi Keperawatan Berbasis Checklist Terhadap Mutu Dokumentasi Asuhan Keperawatan. Jurnal Keperawatan Notokusumo, 2017; Volume V No 1. ISSN2338-4514.

10. Kasim, Mohamad., Abdurrouf, Muh. Peningkatan Kualitas Pelayanan

Dan

Pendokumentasian

Asuha

n Keperawatan Dengan Metode Tim.NurseLine Journal, 2016; Vol. 1 No. 1.ISSN2540-7937.

11. Aly, E. S., Wafaa N., \& Besely, A. Utilization of nursing process in clinical practices: Nurses knowledge and barriers. Journal of American Science, 2013; 1568-574.

12. Daly, G. Nursing perceptions of electronic documentation. (Order No. 1521616, California State University, Long Beach). ProQuest Dissertations and Theses. 2012; 66.

13. Gillies, DA. Manajemen Keperawatan, suatu Pendekatan Sistem. Philadephia : W.B. Saunders Company. 2009.

14. Top, M., \& Gider, Ö. Nurses' views on electronic medical records (EMR) in turkey: An analysis according to use, quality and user satisfaction. Journal of Medical Systems. 2012; 36 (3), 1979-1988.

15. Siswanto, L. H., Hariyati, . T. S., \& Sukihananto, S. Faktor- Faktor yang berhubungan dengan kelengkapan pendokumentasian asuhan keperawatan. Jurnal

Keperawatan Indonesia. 2013. 16
(2), 77-84.

16. Cruz, Sandra., Antonio Luis Carvalho., Pedro Barbosa., Barbara. Morse fall scale user's manual: Quality in Supervision and in nursing practice. Procedia, 2015;334-339.

17. Nwosisi, E., Carl, L., \& Christopher. A meta-analysis summary of information technology lack of connectivity and usability in patient centered care. International Journal of Engineering and Technology, 2012; 4 (5),512-517.

18. Setyaningrum, Ikawati.,Hariyati, R. T. S., Novieastari, Enie. Peningkatan Kelengkapan Dokumentasian

KepuasanPerawat Pada

Pengawasan Hospital Acquired Infections (Hais) Berbasis Komputer. Jurnal Keperawatan Indonesia. 2016. Volume 19 No.1, pISSN 1410-4490, elSSN 23549203.

19. Sudarianto. Modifikasi Aplikasi Sisfomas Dalam Rangka Penerapan Rekam Kesehatan Elektronik Di Sulawesi Selatan. Dinas Kesehatan Provinsi Sulawesi Selatan. download.portalgaruda.org. 2008.

20. Setyawan, Dedy. Analisis Implementasi Pemanfaatan

Sistem Informasi Manajemen Rumah Sakit (Simrs) Pada Rsud Kardinah Tegal. Indonesian Journal on Computer and Information Technology. 2016. Vol 1 No2. 